\title{
Sinomenine influences capacity for invasion and migration in activated human monocytic THP-1 cells by inhibiting the expression of MMP-2, MMP-9, and CD147
}

\author{
Yang-qiong OU, Li-hua CHEN, Xue-jun LI, Zhi-bin LIN, Wei-dong LI* \\ Department of Pharmacology, School of Basic Medical Sciences, Peking University Health Science Center, Beijing 100191, China
}

\begin{abstract}
Aim: The aim of this study was to investigate the mechanism of the effects of Sinomenine (SIN) on the invasion and migration ability of activated human monocytic THP-1 cells (A-THP-1). Sinomenine is a pure alkaloid extracted from the Chinese medical plant Sinomenium acutum.

Methods: Human monocytic THP-1 cells were induced to differentiate into macrophages with phorbol 12-myristate 13-acetate (PMA). Cells were treated with different concentrations of SIN. The invasion and migration ability of cells was tested by in vitro transwell assays. The levels of CD147 and MMPs were evaluated by flow cytometric analysis and zymographic analysis, respectively. The mRNA expression of CD147, MMP-2, and MMP-9 was measured by RT-PCR.

Results: The invasion and migration ability of A-THP-1 cells was significantly inhibited by SIN in a concentration-dependent fashion; at the same time, the levels of CD147, MMP-2, and MMP-9 were markedly down-regulated. This inhibitory effect was most notable at concentrations of $0.25 \mathrm{mmol} / \mathrm{L}$ and $1.00 \mathrm{mmol} / \mathrm{L}(P<0.01)$.

Conclusion: A possible mechanism of the inhibitory effect of SIN on cell invasion and migration ability is repression of the expression of MMP-2 and MMP-9, which strongly correlates with the inhibition of CD147 activity.
\end{abstract}

Keywords: sinomenine; rheumatoid arthritis; invasion; migration; CD147; MMP-2; MMP-9

Acta Pharmacologica Sinica (2009) 30: 435-441; doi: 10.1038/aps.2009.21; published online 23rd March 2009

\section{Introduction}

Sinomenine (SIN, 7,8-didehydro-4-hydroxy-3,7-dimethoxy-17-methylmorphinan-6-one, $\mathrm{C}_{19} \mathrm{H}_{23} \mathrm{NO}_{4}$ ), an alkaloid isolated from the Chinese medicinal plant, Sinomenium acutum, has been utilized to safely treat arthritis for many years. Previous studies have demonstrated that SIN has a variety of pharmacological effects, including anti-inflammatory effects, immunosuppression, and prevention of cartilage destruction ${ }^{[1-4]}$. As an immunosuppressive agent, SIN has been used extensively in China for the treatment of rheumatoid arthritis ${ }^{[5,6]}$.

Rheumatoid arthritis (RA) is a systemic, immune and inflammatory disease characterized by joint swelling, synovial inflammation and joint destruction, leading to significant disability ${ }^{[7]}$. The regulation of cell migration and invasion is a critical process throughout the development of RA.

* Correspondence to Wei-dong LI.

E-mail lwdpharma@126.com

Received 2008-12-19 Accepted 2009-02-10
Enhanced migration and invasion of peripheral macrophages contribute to joint destruction in RA by directly degrading the cartilage matrix and indirectly promoting angiogenesis. Elevated gene expression of gelatinase A (also called matrix metalloproteinase-2, MMP-2) and gelatinase B (also called matrix metalloproteinase-9, MMP-9) is critical for the progression of $\mathrm{RA}^{[8]}$.

The extracellular matrix metalloproteinase inducer (EMMPRIN, CD147) is a heavily glycosylated protein containing two immunoglobulin super family domains. It is enriched on the surface of macrophages and is associated with differentiation of human monocytic THP-1 cells when treated with phorbol 12-myristate 13-acetate (PMA). This protein stimulates the production of matrix metalloproteinases (MMPs). CD147 has also been reported to play an important role in the invasion and migration ability of cells in both animal models and cancer patients ${ }^{[9]}$.

Although many in vivo studies have demonstrated that SIN can significantly improve $\mathrm{RA}^{[10-12]}$, the specific mechanism of SIN has not been established. The purpose of this 
study was to investigate the effects of SIN on the invasion and migration ability of activated human monocytic THP-1 cells (A-THP-1) and to evaluate the underlying mechanism.

\section{Materials and methods}

Materials SIN was donated for use in our laboratory by Hu-nan Zheng Qing Pharmaceutical Factory. Human monocytic THP-1 cells were obtained from Peking Union Medical College. All reagents used for cell culture containing penicillin/streptomycin, pyruvate, FCS (fetal calf serum) and RPMI-1640 medium were purchased from Gibco BRL (Grand Island, NY). Phorbol 12-myristate 13-acetate (PMA) was purchased from Sigma Chemical Co (St Louis, MO). Restriction enzymes and Taq polymerase were obtained from Takara, and FITC-labeled anti-human CD147 antibody was purchased from the Ancell Corporation (USA).

Cell culture and differentiation Human monocytic THP-1 cells were cultured in RPMI-1640 medium supplemented with $10 \%$ heat-inactivated fetal bovine serum, 2 $\mathrm{mmol} / \mathrm{L}$, $L$-glutamine, $5 \mathrm{mmol} / \mathrm{L}$ sodium pyruvate, and antibiotics $\left(10^{5} \mathrm{U} / \mathrm{L}\right.$ penicillin, $10^{5} \mathrm{U} / \mathrm{L}$ streptomycin) in culture flasks. Cells were maintained at $37^{\circ} \mathrm{C}$ in a humidified $5 \%$ $\mathrm{CO}_{2}$ atmosphere. Experiments were routinely carried out using cells in the log phase of growth. PMA was dissolved in DMSO to obtain a $1 \mathrm{mmol} / \mathrm{L}$ stock solution and further diluted with PBS before use. For all experiments, THP-1 cells were cultured at an initial density of $5 \times 10^{8}$ cells/L and treated with PMA at a final concentration of $50 \mu \mathrm{g} / \mathrm{L}$ for $24 \mathrm{~h}^{[13]}$. After being washed three times with complete medium, cells were plated at a suitable density and left to recover and adhere for $24 \mathrm{~h}$ in the incubator. A-THP- 1 cells used in these experiments were all treated in the same manner.

MTT assay A-THP-1 cells were suspended in RPMI -1640 medium with $10 \%$ FCS, plated onto gelatinized 96-well culture plates $\left(5 \times 10^{8}\right.$ cells $/ \mathrm{L}, 0.1 \mathrm{~mL} /$ well $)$, and incubated at $37^{\circ} \mathrm{C}$ with $5 \% \mathrm{CO}_{2}$ for $24 \mathrm{~h}$. Then, the medium was replaced with $0.1 \mathrm{~mL}$ of RPMI-1640, containing different concentrations of $\operatorname{SIN}(0,0.01,0.05,0.25$, and 1.00 $\mathrm{mmol} / \mathrm{L}$ ), and incubated for $48 \mathrm{~h}$ at $37^{\circ} \mathrm{C}$ with $5 \% \mathrm{CO}_{2}$. Cell viability was determined by $\mathrm{MTT}$ assay. In the MTT assay, 20 $\mu \mathrm{L}$ of MTT was added to each well (final MTT concentration was $0.5 \mathrm{~g} / \mathrm{L}$ ) for $4 \mathrm{~h}$ before the addition of $150 \mu \mathrm{L}$ DMSO to solubilize the reactive dye. The absorbance value of each well was recorded at $570 \mathrm{~nm}$ using a Bio-Rad microplate reader $^{[14]}$.

In vitro cell invasion and migration assays In vitro cell invasion assays were performed in 10-mm diameter and $8 \mu \mathrm{m}$ pore polycarbonate filter transwell plates (Millipore). Membranes were precoated with $25 \mu \mathrm{g}$ of matrigel (Peking University Health Science Center) on the upper surface, which formed a reconstituted basement membrane at $37^{\circ} \mathrm{C}$. After treatment with $\operatorname{SIN}(0,0.01,0.05,0.25$, and $1.00 \mathrm{mmol} / \mathrm{L})$ for $48 \mathrm{~h}, \mathrm{~A}$-THP-1cells $\left(5 \times 10^{5}\right.$ cells in $100 \mu \mathrm{L}$ RPMI-1640) were seeded onto the upper well of the chamber, and the lower well was filled to the top $(500 \mu \mathrm{L})$ with RPMI-1640 containing $10 \% \mathrm{FCS}$ as a chemoattractant ${ }^{[15]}$. After incubation for $24 \mathrm{~h}$ at $37^{\circ} \mathrm{C}$ in the presence of $5 \% \mathrm{CO}_{2}$, the cells were fixed for $30 \mathrm{~min}$ in $4 \%$ formaldehyde and stained for 15 min with crystal violet. The non-migrating cells were then carefully removed from the upper surface (inside) of the transwell with a wet cotton swab. Cells that had migrated or invaded to the bottom surface of the filter were counted. Six evenly spaced fields of cells were counted in each well using an inverted phase-contrast microscope.

There was no matrigel precoated on membranes of the upper surface in in vitro invasion assays. Other conditions were the same as in the migration assays ${ }^{[16]}$.

Isolation of total RNA and RT-PCR Total RNA was extracted from A-THP-1cells cells treated with $\operatorname{SIN}(0,0.01$, $0.05,0.25,1.00 \mathrm{mmol} / \mathrm{L})$ for $48 \mathrm{~h}\left(5 \times 10^{8}\right.$ cells $\left./ \mathrm{L}\right)$ using Trizol reagent (Invitrogen, Cergy Pontoise, France) according to the manufacturer's instructions.

Reverse-transcription reaction components were as follows: total RNA $(2 \mu \mathrm{g})$, random primer ( $5 \mathrm{pmol} / \mathrm{L}), \mathrm{M}-\mathrm{MLV}$ reverse transcriptase $(0.5 \mathrm{U}: 1 \mu \mathrm{L}), \mathrm{dNTP}(1 \mathrm{mmol} / \mathrm{L})$, and $1 \times \mathrm{RT}$ buffer. The reaction volume was brought up to $20 \mu \mathrm{L}$ with nuclease-free water. All components were mixed on ice and then reacted for $60 \mathrm{~min}$ at $37^{\circ} \mathrm{C}$ and $15 \mathrm{~min}$ at $72^{\circ} \mathrm{C}$.

PCR reaction components were as follows: $\mathrm{RT}$ product mix $(4 \mu \mathrm{L})$, primers $(0.5 \mu \mathrm{mol} / \mathrm{L}$ of each, for sequences see Table 1$)$, Taq polymerase ( $0.1 \mathrm{U}: 1 \mu \mathrm{L}), \mathrm{MgCl}_{2}(1.5$ $\mathrm{mmol} / \mathrm{L})$, dNTP $(0.125 \mathrm{mmol} / \mathrm{L}$ of each), and $1 \times$ PCR buffer. The usual temperature programs were $5 \mathrm{~min}$ at $94^{\circ} \mathrm{C}$, then $45 \mathrm{~s}$ at $94^{\circ} \mathrm{C}$ for $24-30$ cycles, $1 \mathrm{~min}$ at $58-61^{\circ} \mathrm{C}$ (Table 2 ), and $1 \mathrm{~min}$ at $72^{\circ} \mathrm{C}$, followed by a final 10 -min extension at $72{ }^{\circ} \mathrm{C}^{[17,18]}$.

The mixture of PCR products was analyzed by electrophoresis in $1.5 \%$ agarose gels stained with ethidium bromide. The ratio between the sample RNA and human glyceraldehyde 3-phosphate dehydrogenase (GAPDH) was calculated to normalize for initial variations in the sample concentration and as a control for reaction efficiency. Images of the RTPCR ethidium bromide-stained agarose gels were acquired with a digital Kodak camera (Eastman Kodak Company, Rochester, NY, USA). Quantification of the bands was analyzed by imaging analysis software from Kodak. 
Table 1. Primer sequences used in PCR.

\begin{tabular}{|c|c|c|c|}
\hline & Forward $\left(5^{\prime} \rightarrow 3^{\prime}\right)$ & Reverse $\left(5^{\prime} \rightarrow 3^{\prime}\right)$ & Size (bp) \\
\hline MMP-2 & ATGACAGCTGCACCACTGAG & GCCTCGTATACCGCATCAAT & 474 \\
\hline MMP-9 & GTGCTGGGCTGCTGCTTTGCTG & GTCGCCCTCAAAGGTTTGGAAT & 294 \\
\hline CD147 & AGCGGTTGGAGGTTGTAGG & TGGCACGGACTCTGACTTG & 435 \\
\hline GAPDH & GCCAAGGTCATCCATGACAAC & GTCCACCACCCTGTTGCTGTA & 498 \\
\hline
\end{tabular}

Table 2. Annealing temperature and cycles used in PCR.

\begin{tabular}{lcc}
\hline & PCR annealing temperature $\left({ }^{\circ} \mathrm{C}\right)$ & Cycles \\
\hline MMP-2 & 58 & 28 \\
MMP-9 & 61 & 30 \\
CD147 & 58 & 28 \\
GAPDH & 58 & 24 \\
\hline
\end{tabular}

Flow cytometric analysis After being treated with SIN $(0,0.01,0.05,0.25$, and $1.00 \mathrm{mmol} / \mathrm{L})$ for $48 \mathrm{~h}, \mathrm{~A}-\mathrm{THP}-1$ cells $\left(5 \times 10^{8}\right.$ cells $\left./ \mathrm{L}\right)$ were washed with phosphate-buffered saline (PBS). Cells were labeled with fluorescein isothiocyanate-labeled anti-CD 147 antibody for $45 \mathrm{~min}$ at $4{ }^{\circ} \mathrm{C}$ and then washed with cold PBS and suspended in PBS. Labeled cells were analyzed on a Cytoron flow cytometer.

Zymographic analysis Cells were harvested at the exponential growth phase, washed three times in serum-free RPMI-1640, plated onto gelatinized 24-well culture plates $(0.5 \mathrm{~mL} /$ well $)$ at a density of $5 \times 10^{8}$ cells $/ \mathrm{L}$, and incubated for $48 \mathrm{~h}$ in the absence (control) or presence of SIN (0.01, $0.05,0.25$, and $1.00 \mathrm{mmol} / \mathrm{L})$. The supernatants were collected, centrifuged to remove debris, and analyzed by zymography.

Gelatinolytic activities were assessed under non-reducing conditions using modified sodium dodecyl sulfate polyacrylamide gel electrophoresis (SDS-PAGE). This technique was performed on a $7.5 \%$ polyacrylamide gel copolymerized with $0.1 \%$ gelatin type I. Twenty microliter samples mixed with $10 \mu \mathrm{L}$ of loading buffer were run under non-reducing conditions without prior boiling. After electrophoresis, gels were washed two times with $2.5 \%$ Triton X-100 to remove SDS and allow proteins to renature and then immersed in buffer ( $50 \mathrm{mmol} / \mathrm{L}$ Tris, $\mathrm{pH} 7.5,5 \mathrm{mmol} / \mathrm{L} \mathrm{CaCl}_{2}, 1 \mu \mathrm{mol} / \mathrm{L}$ $\mathrm{ZnCl}_{2}$ and $0.01 \% \mathrm{NaN}_{3}$ ) for $18 \mathrm{~h}$ at $37^{\circ} \mathrm{C}$. Gels were stained with $0.2 \%$ Coomassie ( $0.25 \%$ brilliant blue, $40 \%$ methanol, $7.5 \%$ acetic acid) for $4 \mathrm{~h}$ at room temperature, followed by treatment with destaining buffer (30\% methanol, 10\% acetic acid) until the desired contrast was achieved. A clear white band showing proteolytic activity was detected against a blue background of undigested gelatin. Gels were documented using an Epi ChemII darkroom (UVP Inc, Upland, CA) documentation system, and the intensity of the bands was quantified using imaging analysis software from Kodak ${ }^{[19]}$.

Statistical analysis The statistical significance $(P<0.05)$ of differences was evaluated by ANOVA using the SPSS (10.0) statistics package. All results were expressed as means \pm standard deviation (SD).

\section{Results}

Cell differentiation For all experiments, THP-1 cells were cultured at an initial density of $5 \times 10^{8}$ cells $/ \mathrm{L}$ and treated with PMA at a final concentration of $50 \mu \mathrm{g} / \mathrm{L}$. After 24 h, over $90 \%$ of THP-1 cells adhered to the plastic as macrophage-like cells when observed under a microscope.

The effects of SIN on cell viability Cells $\left(5 \times 10^{8}\right.$ cells $/ \mathrm{L})$ were incubated with various concentrations of $\operatorname{SIN}(0,0.01,0.05,0.25$, and $1.00 \mathrm{mmol} / \mathrm{L})$ for $48 \mathrm{~h}$. The absorbance value of each well at $570 \mathrm{~nm}$ was read in a BioRad microplate reader. The results showed no changes in viability of A-THP-1 cells resulting from the addition of SIN (Figure 1).

In vitro cell invasion and migration assays Cell inva-

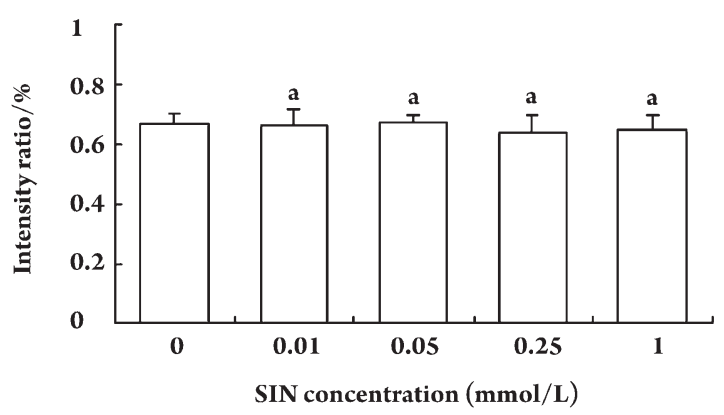

Figure 1. Growth curve of A-THP-1 cells in RPMI 1640 with $10 \%$ FCS. Cells $\left(5 \times 10^{8}\right.$ cells $\left./ \mathrm{L}\right)$ were incubated with various concentrations of $\operatorname{SIN}(0,0.01,0.05,0.25$, and $1.00 \mathrm{mmol} / \mathrm{L})$ for $48 \mathrm{~h}$. The intensity ratio (\%) indicates the cell viability at other drug concentrations as compared with the control. $n=6$. Mean \pm SD. ${ }^{a} P>0.05 v s$ control. 
sion through the matrigel basement membrane in the cell invasion assay and cell migration directly through the membrane in the cell migration assay were analyzed in a modified transwell plate. Cells that invaded to the lower surface of the membrane in these assays were fixed and stained (Figure 2). The percentage of migration and invasion of A-THP-1 cells was significantly lower in the $0.05 \mathrm{mmol} / \mathrm{L}$ SIN treatment group $(P<0.05)$. Migration was also significantly reduced in the 0.25 and $1.00 \mathrm{mmol} / \mathrm{L}$ SIN treatment groups $(P<0.01)$.

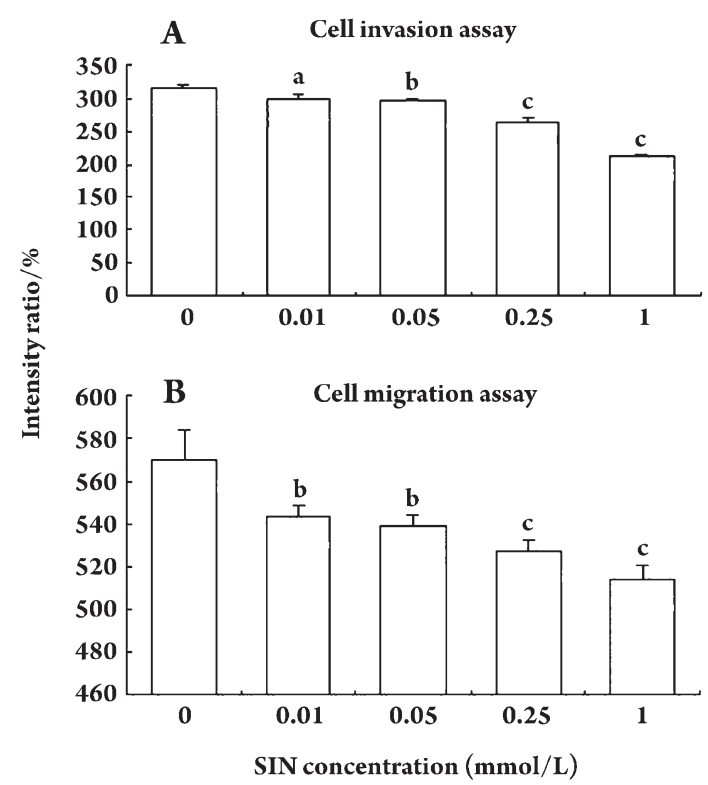

Figure 2. Cell invasion and migration assay in $\operatorname{SIN}(0,0.01,0.05,0.25$, and $1.00 \mathrm{mmol} / \mathrm{L})$ treated A-THP- 1 cells $\left(5 \times 10^{8}\right.$ cells $\left./ \mathrm{L}\right)$. Mean cell counts from 6 random fields and data represent the mean \pm SD of three independent experiments. ${ }^{\mathrm{a}} \mathrm{P}>0.05,{ }^{\mathrm{b}} \mathrm{P}<0.05,{ }^{\mathrm{c}} \mathrm{P}<0.01$ vs control.

The effects of SIN on CD147, MMP-2, and MMP-9 gene expression In order to study the effect of SIN on CD147, MMP-2, and MMP-9 production at the transcriptional level, A-THP-1 cells were maintained in culture in the presence of SIN for $48 \mathrm{~h}$. The total RNA of cells was isolated and RT-PCR was performed as described under Methods. As shown in Figure 3, the level of CD147 mRNA was down regulated in the $0.25 \mathrm{mmol} / \mathrm{L}$ and $1.00 \mathrm{mmol} / \mathrm{L}$ SIN treatment groups $(P<0.05)$. The level of MMP-2 and MMP-9 mRNA was efficiently and dose-dependently downregulated by SIN; a significant reduction was observed in the 0.05 $\mathrm{mmol} / \mathrm{L}$ SIN treatment group $(P<0.05)$, and it was highly significant in the $0.25 \mathrm{mmol} / \mathrm{L}$ and $1.00 \mathrm{mmol} / \mathrm{L}$ SIN treatment groups $(P<0.01)$.

The effects of SIN on levels of CD147 FITC-labeled A-THP-1 cells were treated with various concentrations of
SIN for $48 \mathrm{~h}$. SIN-mediated inhibition of CD 147 release was dose-dependent, with the maximal effects obtained in the $0.25 \mathrm{mmol} / \mathrm{L}$ and $1.00 \mathrm{mmol} / \mathrm{L}$ SIN treatment groups $(P<0.01)$. A significant inhibition of CD147 release was also observed in the $0.05 \mathrm{mmol} / \mathrm{L}$ SIN treatment group $(P<0.05)$ (Figure 4). The data indicate that the decreased CD147 protein levels result from a downregulation of $\mathrm{CD} 147$ at the mRNA level.

\section{The effects of SIN on activities of MMP-2 and MMP-9} Gelatinolytic activities of MMP-2 and MMP-9 in conditioned medium were detected by electrophoresis of the soluble protein on a gelatin containing $7.5 \%$ polyacrylamide gel. These experiments show that the suppression of enzyme activity of MMP-2 and MMP-9 was more pronounced in the groups treated with SIN when compared with the control group. The observed suppression in enzymatic activity was significant in the $0.05 \mathrm{mmol} / \mathrm{L}(P<0.05), 0.25$ and 1.00 $\mathrm{mmol} / \mathrm{L}$ SIN treatment groups $(P<0.01)$ (Figure 5$)$.

\section{Discussion}

Matrix metalloproteinases (MMPs), which are also known as matrixins, comprise a family of zinc-containing endopeptidases that share common structural domains. These proteins have the capacity to degrade extracellular matrix (ECM) components, as well as alter their biological functions.

The MMPs are categorized into three major functional groups, in part based on substrate specificity. The interstitial collagenases (MMP-1, -8, and -13), which preferentially have affinities for collagen types I, II, and III, the stromelysins (MMP-3, -10, and -11), with specificity for laminin, fibronectin, and proteoglycans, and the gelatinases (MMP-2 and -9), which are most effective in the cleavage of type IV and V collagen, represent the three main groups.

The regulation of gene expression of most MMPs is controlled by CD147/EMMPRIN ${ }^{[20,21]}$. CD147/EMMPRIN is a highly glycosylated cell surface transmembrane protein found on the cell surface of many types of cells, including differentiated macrophages. It has been implicated in inducing MMP synthesis in rheumatoid synovium, in the surrounding fibroblasts after injury involving stromal remodeling, and in other situations associated with discontinuity of the basement membrane. But CD 147 has no effect on the physiological inhibitors of MMP production and activation, TIMP-1 or TIMP-2, so the effects of TIMP on MMPs are not changed by $\mathrm{CD} 147^{[22-24]}$.

MMPs transcripts are generally expressed at low levels, but these levels rise rapidly when tissues are locally induced 
A
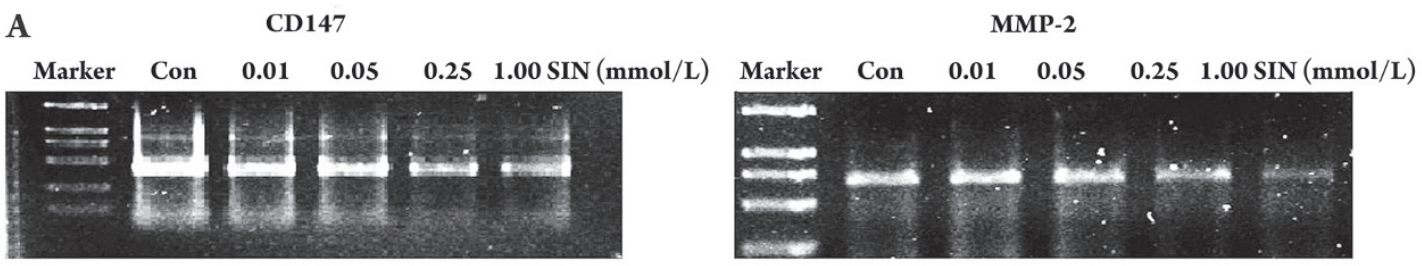

MMP-9

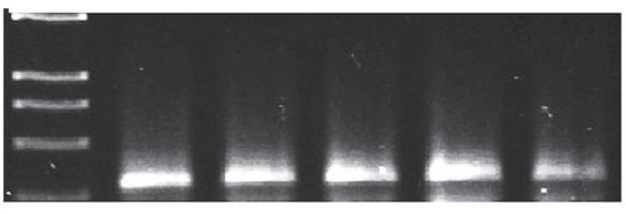

GAPDH

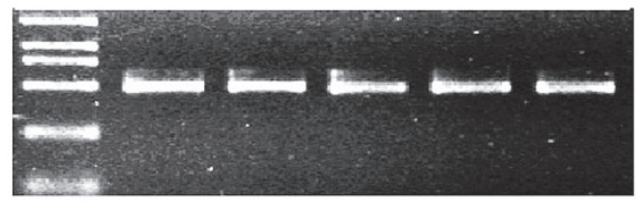

B
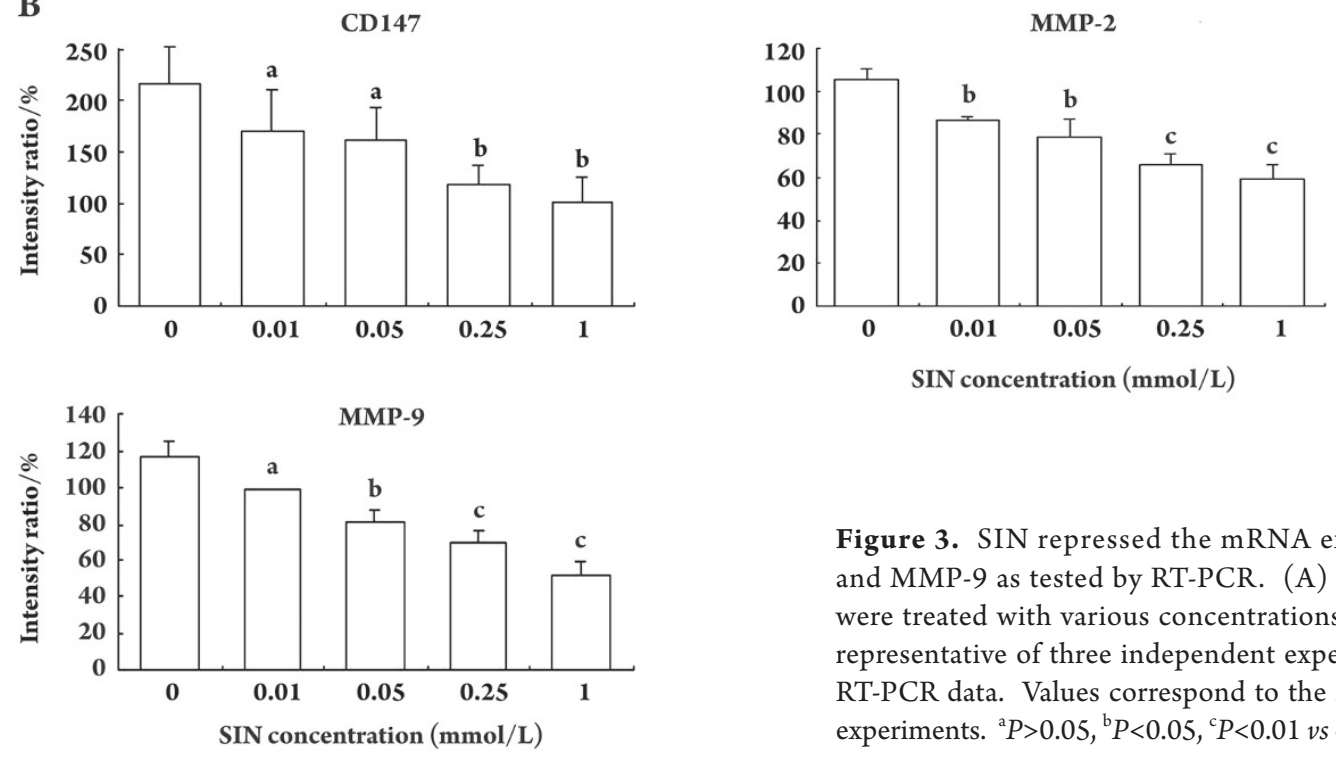

Figure 3. SIN repressed the mRNA expression of CD147, MMP-2, and MMP-9 as tested by RT-PCR. (A) A-THP- 1 cells $\left(5 \times 10^{8}\right.$ cells/L) were treated with various concentrations of SIN for $48 \mathrm{~h}$. The data are representative of three independent experiments. (B) Quantification of RT-PCR data. Values correspond to the mean \pm SD of three independent experiments. ${ }^{\mathrm{a}} \mathrm{P}>0.05,{ }^{\mathrm{b}} \mathrm{P}<0.05,{ }^{\mathrm{c}} \mathrm{P}<0.01$ vs control.

to undergo remodeling in events such as inflammation, wound healing, cancer, and arthritis. MMPs including MMP-2 and MMP-9 contribute to joint destruction in RA by enhancing the migration and invasion ability of macrophages. Therefore, inhibition of MMPs is a primary therapeutic target in RA and improvements in therapeutic indices may be achieved by targeting specific MMPs.

Sinomenine is a promising immunosuppressive drug that has been widely used for treating autoimmune diseases like RA because of its excellent therapeutic effect and relatively insignificant side effect profile. However, the molecular mechanism of SIN has not yet been completely elucidated.

Due to the crucial role of cell migration and invasion in the pathology of RA and the important role of CD147 in the synthesis of gelatinases (MMP-2 and -9) in RA, the effects of SIN on cell migration and invasion and its possible mechanism were investigated using an in vitro transwell assay. Human monocytic THP-1 cells were induced to differenti-

ate into macrophages with phorbol 12-myristate 13-acetate $(\mathrm{PMA})^{[25,26]}$, and cells were then treated with SIN at various concentrations. Cellular invasion and migration ability was inhibited by SIN, particularly at concentrations of 0.05 $\mathrm{mmol} / \mathrm{L}(P<0.05), 0.25$ and $1.00 \mathrm{mmol} / \mathrm{L}(P<0.01)$. The expression of CD147, MMP-2, and MMP-9 mRNA, as measured by RT-PCR, was down-regulated by SIN at concentrations of 0.25 and $1.00 \mathrm{mmol} / \mathrm{L}(P<0.05)$. The protein levels of CD147, as measured by flow cytometric analysis, were decreased by SIN at concentrations of $0.05(P<0.05), 0.25$ and $1.00 \mathrm{mmol} / \mathrm{L}(P<0.01)$. The enzyme activity of MMP-2 and MMP-9, as measured by Zymographic analysis, was suppressed by SIN at concentrations of $0.05(P<0.05), 0.25$ and $1.00 \mathrm{mmol} / \mathrm{L}(P<0.01)$. These data demonstrate that SIN can significantly repress the invasion and migration ability of macrophages in a dose-dependent manner, and this repression strongly correlates with the inhibition of CD 147, MMP2 , and MMP-9 activity. Cell viability assay showed that all of 

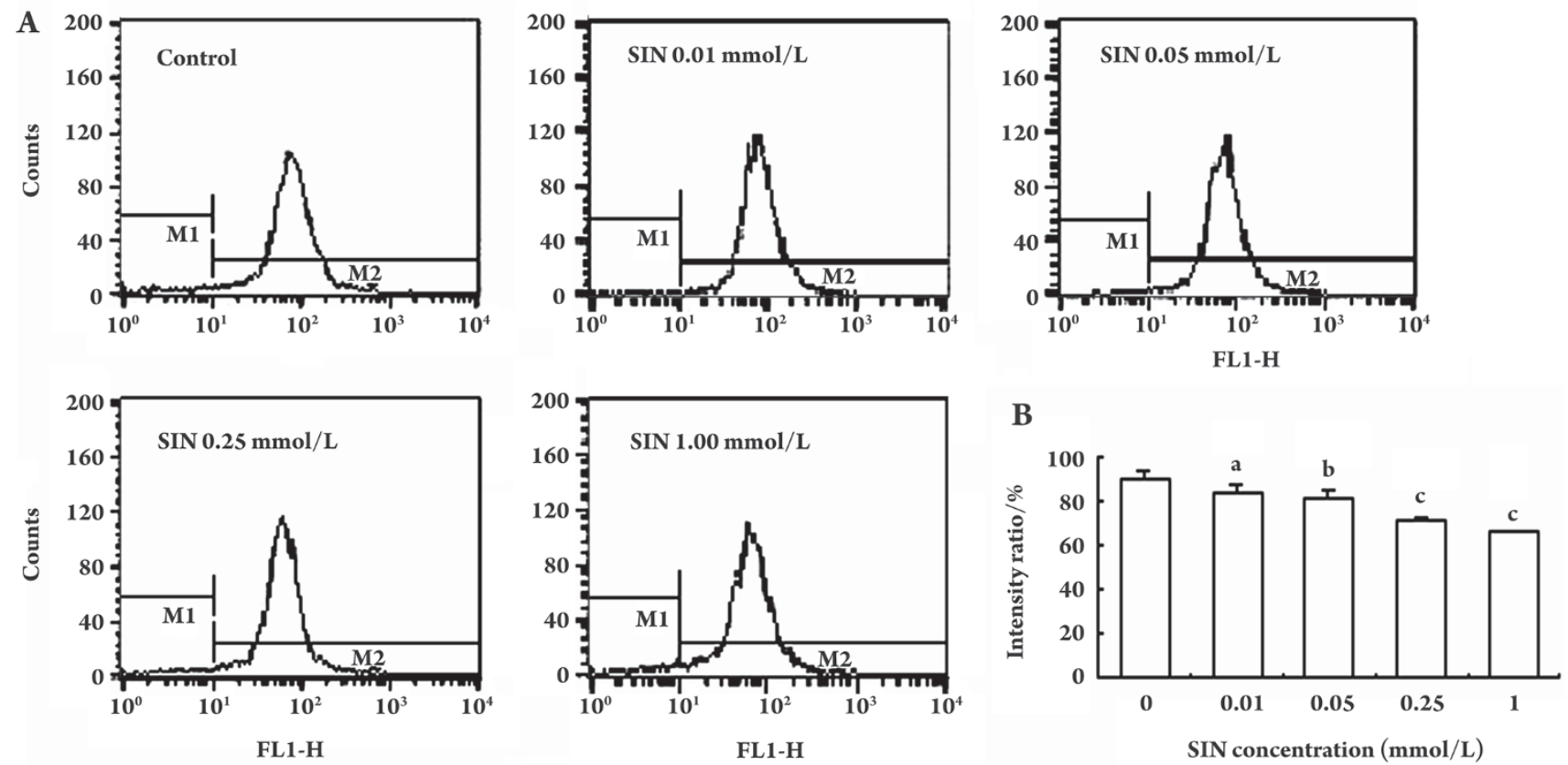

Figure 4. (A) Flow cytometric analysis of the effect of SIN on the expression of CD147 in A-THP- 1 cells. A-THP- 1 cells ( $5 \times 10^{8}$ cells/L) were incubated with SIN for $48 \mathrm{~h}$. Expression of CD147 was analyzed with a Cytoron flow cytometer. (B) Quantification of flow cytometric analysis data. Values correspond to the mean \pm SD of three independent experiments. ${ }^{a} P>0.05,{ }^{b} P<0.05,{ }^{c} P<0.01$ vs control.

A
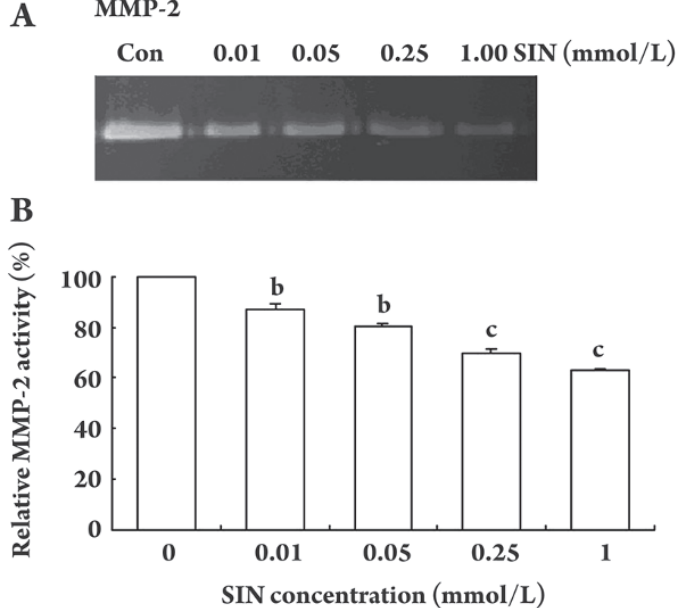

MMP-9
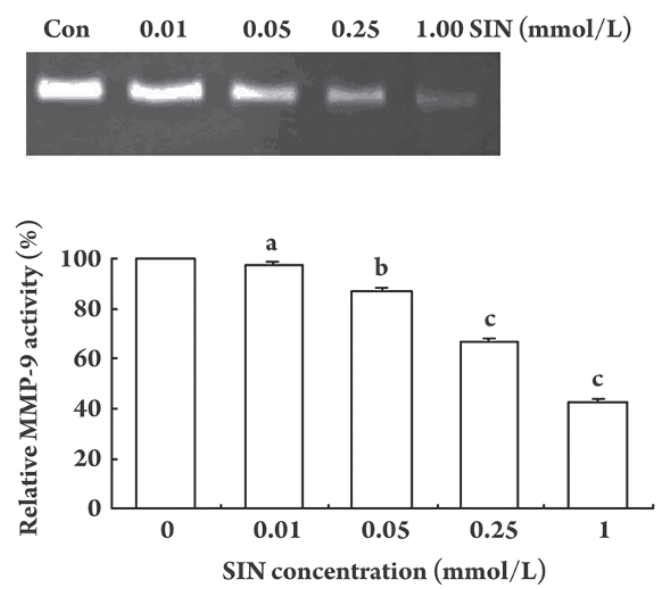

Figure 5. Gelatin zymography for the determination of MMP- 2 and MMP- 9 activities in SIN treated A-THP- 1 cells. (A) A-THP- 1 cells $\left(5 \times 10^{8}\right.$ cells/L) were treated with various concentrations of $\operatorname{SIN}(0,0.01,0.05,0.25$, and $1.00 \mathrm{mmol} / \mathrm{L})$ for $48 \mathrm{~h}$, and activities of MMP-2 and MMP-9 in conditioned media were evaluated by electrophoresis of soluble protein on a gelatin containing $7.5 \%$ polyacrylamide gel. (B) Areas and relative intensities of gelatin digested bands by MMP-2 and MMP-9 were quantified by densitometry and expressed as relative activity compared to that of the RPMI-1640 control group. Values correspond to the mean \pm SD of three independent experiments. ${ }^{a} P>0.05,{ }^{b} P<0.05,{ }^{c} P<0.01 v s$ control.

these effects occured without inhibiting A-THP-1 cell viability in vitro.

Taken together, our study provides a new mechanism by which SIN exerts its function in RA. In summary, the effects of SIN on invasion and migration ability of macrophages may be achieved through the inhibition of MMP-2 and MMP-9 expression by decreasing CD147 expression. 


\section{Acknowledgments}

The authors are very grateful to Prof jian-hui LIANG and Dr Michael A McNutt for revising this paper.

\section{Author contribution}

Yang-qiong OU, Wei-dong LI, and Zhi-bin LIN designed the research; Yang-qiong OU and Li-hua CHEN performed the research; Xue-jun LI and Zhi-bin LIN contributed new analytical reagents and tools; Yang-qiong $\mathrm{OU}$ and Wei-dong LI analyzed the data; and Yang-qiong OU wrote the paper.

\section{References}

1 Zhou H, Wong YF, Wang J, Cai X, Liu L. Sinomenine ameliorates arthritis via MMPs, TIMPs, and cytokines in rats. Biochem Biophys Res Commun 2008; 376: 352-7.

2 Hua H, Chen X. Mechanistic study of sinomenine on analgesic and anti-inflammatory actions. J Xi-an Med Univ 1989; 4: 346-9. Chinese.

3 Liu L, Buchner E, Beitze D, Schmidt-Weber CB, Kaever V, Emmrich F, et al. Amelioration of rat experimental arthritides by treatment with the alkaloid sinomenine. Int J Immunopharmacol 1996; 18: 529-43.

4 Li L, Zhang CL, Song BW. Research of the pharmacological effect of sinomenine and clinical application. Tradit Chin Drug Res Clin Pharmacol 2006; 7: 17-4. Chinese.

5 Li XJ, Yue PY, Ha WY, Wong DY, Tin MM, Wang PX, et al. Effect of sinomenine on gene expression of the IL- $1 \beta$-activated human synovial sarcoma. Life Sci 2006; 79: 665-73.

6 Yamasaki H. Pharmacology of sinomenine, an anti-rheumatic alkaloid from Sinomenium acutum. Acta Med Okayama 1976; 30: $1-20$.

7 Wang Y, Fang YF, Huang WH, Zhou X, Wang MH, Zhong B, et al. Effect of sinomenine on cytokine expression of macrophages and synoviocytes in adjuvant arthritis rats. J Ethnopharmacol 2005; 98: 37-43.

8 Li F, Li XF, Hu XF, Wang XX, Xu K, Chen Z. The serum matrix metalloproteinase- 9 level and its significance in rheumatoid arthritis. Chin J Rheumatol 2005; 9: 554-6. Chinese.

9 Gabison EE, Hoang-Xuan T, Menashi S. EMMPRIN/CD147, an MMP modulator in cancer, development and tissue repair. Biochimie 2005; 87: 361-8.

10 Liu JH, Li WD, Teng HL, Lin ZB. Immunopharmacological action of sinomenine, an alkaloid isolated from Sinomenium acutum, and its mechanism of action in treating rheumatoid arthritis. Acta Pharm Sin 2005; 40: 127-31.

11 Liu L, Buchner E, Beitze D, Schmidt-Weber CB, Kaever V, Emmrich F, et al. Amelioration of rat experimental arthritides by treatment with the alkaloid sinomenine. Int J Immunopharmacol 1996; 18: 529-43.
12 Kok TW, Yue PY, Mak NK, Fan TP, Liu L, Wong RN. The antiangiogenic effect of sinomenine. Angiogenesis 2005; 8: 3-12.

13 Bremner TA, Chatterjee D, Han ZY, Tsan MF, Wyche JH. THP-1 monocytic leukemia cells express Fas ligand constitutively and kill Fas-positive Jurkat cells. Leuk Res 1999; 23: 865-70.

14 Cao QZ, Lin ZB. Ganoderma lucidum polysaccharides peptide inhibits the growth of vascular endothelial cell and the induction of VEGF in human lung cancer cell. Life Sci 2006; 78: 1457-63.

15 Lee SK, Chun HK, Yang JY, Han DC, Son KH, Kwon BM. Inhibitory effect of obovatal on the migration and invasion of HT1080 cells via the inhibition of MMP-2. Bioorg Med Chem 2007; 15: 4085-90.

16 Haa KT, Kim KW, Suh SJ, Kwak CG, Kima JK, Kimb CH. Inhibitory effect of Uncaria sinensis on human aortic smooth muscle cell migration is based on matrix metalloproteinase- 9 inhibitory. Environ Toxicol Pharmacol 2007; 24: 218-22.

17 Zhang B, Wu KF, Cao ZY, Rao Q, Ma XT, Zheng GG, et al. IL18 increases invasiveness of HL-60 myeloid leukemia cells: upregulation of matrix metalloproteinases-9 (MMP-9) expression. Expe Eye Res 2007; 84: 960-72.

18 Cheng H, Xia B, Guo QS, Zhang L, Wang F, Jiang L, et al. Sinomenine attenuates 2,4,6-trinitrobenzene sulfonic acid-induced colitis in mice. Int Immunopharmacol 2007; 7: 604-11.

19 Zylberberg C, Seamon V, Ponomareva O, Vellala K, Deighan M, Azzarolo AM. Estrogen up-regulation of metalloproteinase-2 and -9 expression in rabbit lacrimal glands. Exp Eye Res 2007; 84: 960-72.

20 Ellis SM, Nabeshima K, Biswas C. Monoclonal antibody preparation and purification of a tumor cell collagenase-stimulatory factor. Cancer Res 1989; 49: 3385-91.

21 Kataoka H, DeCastro R, Zucker S, Biswas C. Tumor cell-derived collagenase-stimulatory factor increases expression of interstitial collagenase, stromelysin, and 72-kDa gelatinase. Cancer Res 1993; 53: 3154-8.

22 Guo H, Zucker S, Gordon MK, Toole BP, Biswas C. Stimulation of matrix metalloproteinase production by recombinant extracellular matrix metalloproteinase inducer from transfected Chinese hamster ovary cells. J Biol Chem 1997; 272: 24-7.

23 Taylor PM, Woodfield RJ, Hodgkin MN, Pettitt TR, Martin A, Kerr DJ, et al. Breast cancer cell-derived EMMPRIN stimulates fibroblast MMP2 release through a phospholipase $\mathrm{A}(2)$ and 5-lipoxygenase catalyzed pathway. Oncogene 2002; 21: 5765-72.

24 Polette M, Gilles C, Marchand V, Lorenzato M, Toole B, Tournier JM. Tumor collagenase stimulatory factor (TCSF) expression and localization in human lung and breast cancers. J Histochem Cytochem 1997; 45: 703-9.

25 Tsuchiya S, Yamabe M, Yamaguchi Y, Kobayashi Y, Konno T, Tada K. Establishment and characterization of a human acute monocytic leukemia cell line. Int J Cancer 1980; 26: 171-6.

26 Traore K, Trush MA, George M Jr, Spannhake EW, Anderson W, Asseffa A. Signal transduction of phorbol 12-myristate 13-acetate (PMA)-induced growth inhibition of human monocytic leukemia THP-1 cells is reactive oxygen dependent. Leuk Res 2005; 29: 863-79. 